\title{
Teacher Attrition in a Northern Ontario Remote First Nation: A Narrative Re-Storying
}

\author{
Dawn Burleigh
}

The University of Lethbridge

\begin{abstract}
Increasing teacher retention in First Nations communities has been identified in the literature as requiring attention. When attrition rates are high and teacher efficacy, quality of student experience, and overall academic achievement is compromised, efforts to mobilize plans for stability are needed. Through a narrative re-storying approach this paper unpacks the challenges and opportunities related to teacher attrition in one remote First Nation community in Northern Ontario. Although teacher attrition is inevitable, it is necessary to re-envision attrition factors as a plan for retention. Community integrated induction and mentorship programming, and continuous and multi-year contracts are two possible approaches to boost retention. Teacher education is also explored as a long-term approach to address teacher attrition from a system perspective. In all approaches, collaborative effort, engagement, and funding are needed from the federal government, local education authorities, and faculties of education to increase teacher retention in remote First Nation communities.
\end{abstract}

Keywords: teacher retention; teacher efficacy; attrition factors; mentoring and induction programs

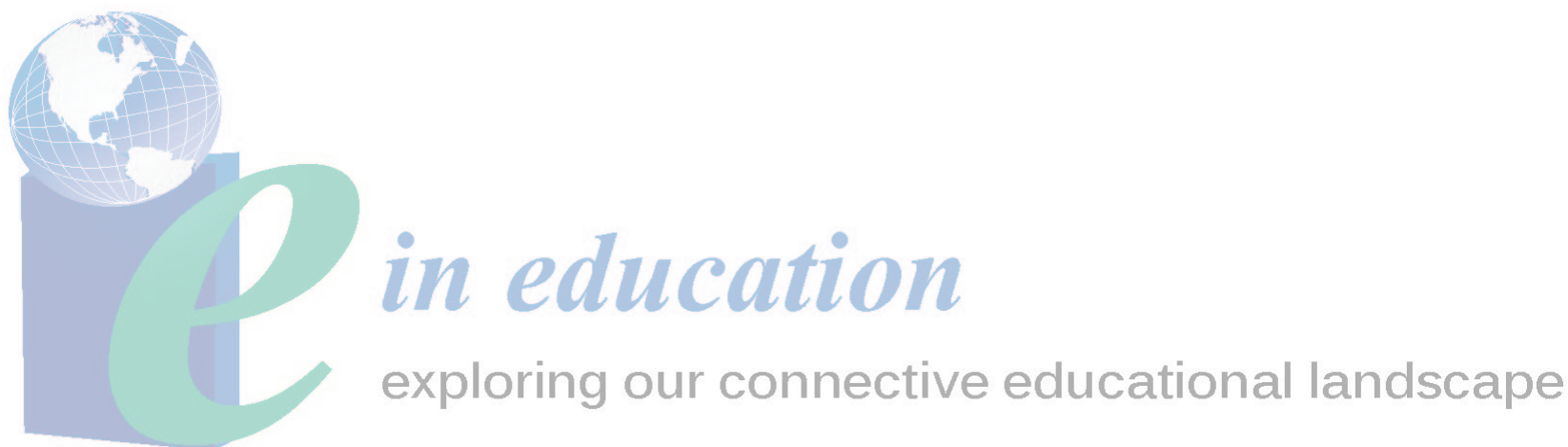




\section{Teacher Attrition in a Northern Ontario Remote First Nation: A Narrative Re-Storying}

Teacher attrition rates in Northern First Nations communities are estimated to be as high as $40 \%$ annually. (Anderson, Orton \& Horwick, 2004; Kitchenham \& Chasteauneuf, 2010; Mueller, Carr-Stewart, Steeves \& Marshall, 2012). This statistic is critically important in the discourse of First Nations education because "teacher recruitment and retention, closely connected with teacher efficacy, are considered as causal factors that influence the quality of student learning and educational achievement” (Mueller et al., 2012). First Nations organizations also have identified teacher attrition and retention as an issue requiring further attention (Chiefs of Ontario, 2004; Assembly of First Nations, 2012). Stability in the teaching force is especially important in the First Nations context because the relational ontology of Indigenous ways of knowing and learning (Ermine, 1995; Simpson, 2000; Wilson, 2007) makes trusting relationships central not only between teachers and students but also with parents and communities as a whole. Furthermore, the problem of teacher retention has assumed new urgency since the Aboriginal population is quickly growing, with a large portion being school-aged children (Statistics Canada, 2008). This demographic reality will compound and magnify issues of teacher attrition and, ultimately, the greatest impact will be felt by students.

To date, explanations for teacher transience in First Nation communities have been linked to the payment of lower salaries, the lack of pensions, the absence of union protection, and a general lack of conditions comparable to what teachers employed in provincial systems enjoy (Anderson et al., 2004; Chiefs of Ontario, 2004; Kitchenham \& Chasteauneuf, 2010; Mueller et al. 2012). Teachers are often responsible for implementing culturally relevant teaching practices, which require ongoing critical reflection, communication, and community engagement (Oshkineegish \& Berger, 2013). Two studies by Wotherspoon $(2006,2008)$ deal directly with teachers' work in Aboriginal communities. Contributing to the recent literature on neoliberalism and educational reform, the focus of these studies is on the intensification of teachers' work and how those points of intensification are in contradiction to the needs of schools in Aboriginal communities. Undoubtedly, all of these factors are relevant as teachers make decisions about staying in or leaving their positions. However, I discovered that factors contributing to attrition are deeply intertwined and connected not only to material circumstances but also to the teachers' desired career progression and their own personal circumstances with family, children, and relationships. Using a narrative re-storying approach, this study unpacks and explores the complexities of teacher attrition, for non-local teachers, in one remote First Nations community in Northern Ontario. To protect confidentiality, I have named this community Grassy Hills. After summarizing the research design, I offer a brief description of Grassy Hills to provide the situating context for the research on teacher attrition. Then I discuss the methodological reasons for utilizing a re-storying approach embedded within the narrative tradition. I then re-story a conversation among four teacher characters who collectively represent all the participants in my inquiry as a method to conversationally reveal considerations that lead to attrition. Finally, a brief discussion highlights some possible options for ameliorating attrition.

\section{Research Design}

This paper reports on part of a larger inquiry that focused on a central question: What is the nature of teachers' work in a remote First Nations community in Northern Ontario? A case study approach was adopted to maintain a scope specific to the teachers and how they conceived of the issues and concerns that dictated their work and lives in the community. A case study approach 
allowed for the depth and richness needed to understand the heavily contextual and complex dynamic of teachers' work.

Both individual interviews and focus groups were conducted during a two-week data collection period in the early spring of 2013. Both elementary and secondary teachers responded to an open call for participation. Fifteen out of a possible 30 teachers actively participated in interviews that lasted an average of one-and-a-half hours, but in some cases up to three hours. I also conducted two focus groups with two and three teachers respectively. The teachers in the focus groups had participated in the individual interviews but expressed an interest in discussing specific issues in more detail in a group setting. It was during these focus groups that the connectivity among the factors contributing to teacher attrition came to life and I could begin to see how certain elements such as compensation were contextualized in more personal circumstances such as student debt or loans. The focus groups provided some of the most specific data revealed in the re-storying.

To protect the identity of the participants and the community, I will not share specific details about individual teachers. However, the 15 participants range in age from 22 to 60 plus and include both male and female teachers. Fourteen of the 15 participants were non-Aboriginal. The participants included experienced teachers, new teachers directly out of teacher education programs, and those for whom teaching was a second career. Some of the teachers had been in the community for more than three years and some had substantial experience working in First Nations schools but were new to the community of Grassy Hills.

\section{The Community}

The community of Grassy Hills is located in the Nishnawbe Aski Nation (NAN) in Northern Ontario. The community is remote and can be reached only by air, which reduces access to goods and services, including food. There are few employment opportunities, and access to clean drinking water, health care, and a variety of other social services is limited and has a negative impact on the daily life of the community's residents. The schools in Grassy Hills, as are all schools in the NAN, are federally funded but the federal government requires adoption of the provincial curriculum and associated policies on the grounds that they are needed to ensure transition opportunities for students who choose to continue to post-secondary education or leave the community to attend provincial schools in more urban areas (Drummond \& Rosenbluth 2013; Paquette \& Fallon, 2010). Teachers are required to have their provincial teaching certification through the Ontario College of Teachers and must be prepared to implement the Ontario provincial curriculum along with the local mandate to include more culturally relevant content for students through the existing curriculum.

Teachers are hired on contracts for a period of one academic school year. Each spring, contract renewals occur and often teachers are offered a contract and asked to return. Occasionally a teacher may not get such an offer of contract extension. During this period of contract renewal, teachers regularly engage with one another to discuss their thoughts about either accepting a contract renewal or declining and moving on to other opportunities. The teachers in Grassy Hills and many other First Nations schools in NAN, do not have union or federation representation. As a result, the teachers are entirely subject to the conditions and terms of their individual contracts. This often results in the assignment of additional teaching responsibilities and extracurricular commitments as well as compromised preparation time. 
Compensation, benefit packages, and pension contributions are an active part of the recruitment and retention process (Mueller et al. 2012). However, the teachers in Grassy Hills are placed on a pay grid through an evaluation process and the benefits and pension contributions are standardized for all teaching staff so although it is a point of discussion, the standardized nature of the compensation and benefits package tends to neutralize comparative conversations within the teaching staff. According to participants, compensation, benefits, and pension contributions in Grassy Hills are comparable to the provincial average with the added benefit that housing is partially subsidized.

\section{Narrative Inquiry and Re-Storying}

The early work in narrative inquiry in education was developed as both a methodology and a way to understand the experiences of teachers (Connelly \& Clandinin, 1990). In this case, I am utilizing narrative inquiry, specifically the process of re-storying, to better understand and make visible the experiences of teachers as they discuss, ponder, and negotiate their roles in the community of Grassy Hills. As already noted, much of the literature on teacher attrition focuses on factors such as compensation, workload, and location but a core goal of narrative inquiry is to study the professional and personal experiences through stories that have seldom been heard (Chase, 2005; Creswell, 2008). In other words, the purpose of narrative inquiry is to ask questions to seek deeper understanding of a particular life experience (Pinnegar \& Dayne, 2007). Utilizing narrative inquiry in this research has allowed the complexities of the experiences of teachers to emerge through story. Such an approach takes on particular significance, since, as I observed in my research journal, participants regularly shared their experiences with me through story.

Re-storying is the researcher's process of taking apart data and then reassembling parts of it into a different narrative framework, in this case a dialogue or conversation among four characters. Creswell (2008) concisely outlines the process of re-storying:

After [the research participants] tell a story about their experiences, narrative researchers retell (or re-story or remap) the story in their own words. They do this to provide order and sequence to it. Re-storying is the process in which the researcher gathers stories, analyzes them for key elements of the story (e.g., time, place, plot, and scene), and then rewrites the story in a chronological sequence. (p. 519)

In the section that follows, I have re-storied themes in the data around factors of attrition. To do this, I have created a dialogue among four teachers who will be introduced in the next section. These four characters represent a convergence of all the participants and bring voice and a collective conversation to bear on teachers' thinking about whether or not they will return for another academic year. It is a story of tensions, decision-making, exploration, and insights into the challenges and opportunities teachers experience during their time living and teaching in a remote First Nations community in Northern Ontario.

\section{Introducing the Participants}

Let me introduce you to Brett, Caitlin, Sue, and Dale, the four composite teacher-characters I have created by attending faithfully to the filed texts I gathered. 
Brett came to teaching as a second career and began his teaching practice in a Grade 8 class in Grassy Hills. He is always engaged in new technologies in education and connects regularly with other teachers in his division to talk about incorporating educational technologies into the classroom. Although Brett has been in the community for three school years, each spring he reconsiders his options. Brett is currently engaged to be married and in the future would like to buy a home and have a family. In his time outside of school, Brett loves coaching the boys' hockey and basketball teams and fishing with work colleagues.

Caitlin is a first-year teacher and started teaching high school English and art in Grassy Hills directly out of her teacher education program. She loves her art programming and enjoyed putting on a student art exhibit this year. Caitlin has substantial student debt and is working toward paying it off. She is an avid cross-country skier and loves the cold and snowy winters. Because she grew up in a small town, Caitlin understands and really enjoys the close-knit community of Grassy Hills and the sense that everyone is connected and knows one another. She also visits regularly with Sue for support and guidance.

Sue is a veteran teacher with more than 20 years in the profession. She teaches Grade 3 in Grassy Hills and has done so for the past five years. She is nearing retirement and brings to Grassy Hills many experiences in teaching both internationally and with First Nations schools from across the country. Sue has three grandchildren and a husband in a southern urban location that she visits as often as possible. Sue is a mentor to many of the new teachers and takes the time to support them and show them the ropes. Sue also brings a wealth of expertise in literacy and her work over the past five years has really helped increase literacy levels in the elementary school.

Dale came to Grassy Hills after 12 years teaching in international contexts around the world. He is originally from a rural town in Northern Ontario and decided to return home and explore the North of his very own province. As a high school geography and history teacher for the past two years, Dale maintains a strong interest in culture, language, and the local history. Dale works with Elders to bring local history to life in his classes and enjoys hunting and trapping with a few friends in the community. He recently has experienced some health issues, and his wife who lives in Southern Ontario is very concerned about him.

Over dinner at Sue’s house, Brett, Caitlin, Sue, and Dale are discussing whether they will return for another year of teaching in the community. It is spring, and the contracts for the next academic year have been delivered. All four have been asked back for another year and the conversation begins as Dale enters the kitchen and asks Sue if she will be returning the next year.

\section{Are You Coming Back Next Year?}

Dale: So, Sue, are you coming back next year?

Sue: That is the question of the day right now isn't it? I am really not sure. There are just so many things to consider. My granddaughter just turned three and I saw the pictures from her birthday party and I feel like I missed a really important event. When things like that-family stuff_comes up it makes it really hard to want to stay. On the other hand, I am so close to retirement and I just love the students here. I can’t imagine teaching anywhere else. Besides, at this point I am just thankful to 
have been offered a contract. I heard Joe wasn’t asked back for another year. What about you Dale?

Dale: I am kind of in the same place. You know, I have had a few health scares lately and my wife back home is really concerned. She thinks I should come home and look for a teaching position in the provincial system so I can be closer to her and health care. But, you know, just last week I had Elders come into the class and it went so well. My history programming is really coming together and I think it has taken the last two years of work to see it all come together now. And plus, the fishing has been amazing this spring! I feel terrible for Joe, but I think many people are just keeping quiet about everything and being thankful for their own contract. No one wants to rock the boat right?

Caitlin: Are you talking about fishing again Dale?

Dale: Of course, have you been yet?

Caitlin: Not yet but I am hoping to get out. The skiing this past winter was just amazing. I got to explore the area and see some places off the river I would never have seen without my skis. I am really excited for next year because I want to take my students and do some activities outside and get out in the community.

Sue: So, you have already decided to come back for another year?

Caitlin: I guess so. To be honest, I have student debt up to my ears and being here is helping me pay it off and helping me to gain experience that I might be able to use one day when I go back to Southern Ontario. I took this job right out of my education program because I knew I would never get hired in Southern Ontario. I don't think it will hurt to stay another year. Although it does scare me knowing that next year I may not get offered a contract. It just makes everything feel so temporary.

Sue: It really is a great experience for you, Caitlin, and you have come such a long way this year.

Caitlin: Thanks Sue. Besides, the art show was a major hit and I have already started talking to artists in the community about joining in next year and having a sale as well. I just don't feel ready to go yet. What about you Brett? You have been here for three years already. What are you doing for next year?

Brett: That's a tough one! I am not sure right now. I am trying to consider all my options. In some ways, I don't want to leave. I am comfortable here and you guys know how much I love my Grade 8 group. We finally got all the iPads into the classes and I really want to see how that will work out for next year. I think my group will be small next year, only 18 students, so that's a bonus, too. But, you know, my fiancée back home is ready to buy a house and start a family so the pull to go home is certainly there.

Dale: That is a tough spot, Brett. It's really hard to maintain those relationships at home when you're here for 10 months of the year. 
Brett: So true. But here is my issue. Even if I wanted to leave and go back home to Southern Ontario, how would I even get to job interviews if I could get one? If an interview happens in May in Toronto, let's say, how would I ask for leave from my position here to go for an interview? It would cost a fortune and then who would cover my class - it's not like we have supply teachers. It's like being between a rock and a hard place. And, the pay here is basically the same as down south. I have been able to save up some money for a down payment.

Caitlin: I didn't think of all that stuff. You guys have some tough decisions. Do you think our experience teaching here is valued in the provincial system? How long can I stay and still make a successful transition to the provincial system?

Sue: Well, Dale, you might have something to say about this because you have also taught internationally, but I think the experience is really valuable and can be translated to other places. But I also know the job market for new teachers is totally different now than when I started.

Dale: Yeah, it's a different world down south, Sue. Most new teachers are competing to just get on a supply list. Most people wait years to get hired on more permanently.

Caitlin: Maybe it's a good thing that I stay here for now. Things down south don't look so good and I don't know if I want to take my chances and maybe get a on a supply list somewhere. Even then it might take years before I get my own class. I just love having so much freedom and flexibility in my teaching here.

Brett: That's true but I guess you have to plan for some transition time. You know I worked in a completely different field than education before I started teaching and it took a few years to get things started. In some ways, I think I might plan my exit from here more than a year in advance. I could save up money to get me through waiting to find a new position. I might even have to go back to my old job just to get me through, but I really don't want to do that.

Dale: This is also such a hard decision to make at this time of year because you start to feel so positive at the end of the school year, you're more reflective and the weather gets nicer and you feel like you will have a rest over the summer. This is not an easy decision. I also find myself asking around about who else will come back, in terms of administration, although I never really trust much of what I hear since there are so many politics. I am glad I can trust you guys.

Sue: For sure, especially the administration! If things were to change drastically with who the principals are right now, that would seriously impact my decision.

Caitlin: Are the principals going to leave?

Brett: Well, they, too, have contracts for only a year so they are probably thinking some of the same things we are.

Caitlin: Oh, if my principal left, I don't know what next year would be like at all. I kind of made my decision assuming most people would be back and things would 
be basically the same. I have seen how other people get stuck with so many extracurriculars and fundraising. I would be worried if a new principal came and delegated all that to me.

Sue: Hopefully most people stay, but every year people leave and new people come and that makes it so hard for the kids and for the teachers who stay as well. It's like every year we are getting to know new people and helping them out.

Caitlin: That's so true Sue. I would be lost without you guys helping me along the way. Who would have been there to help me with my unit plans and figure out how to get keys and everything else you helped me with?

Dale: So true. That's one of the things that really keeps me here: Knowing that I have established really strong routines with the kids and other staff and the new students coming in each fall know me and know what to expect. Each year gets easier with the kids. It's just the politics of the school, the gossip, and trying to fly under the radar that make it tough.

Brett: For sure, you get to know the parents and the students and how everything works. It's one of those things that keep me put. But, you're right, Dale, all the stuff about not knowing what can happen to your job from one day to the next freaks me out and I know I couldn't cope with that in the long-term.

Caitlin: Well, I guess part of it for me was also knowing that Bev and Sam would be back. Since we teach together and live side by side, I felt more comfortable knowing they would be here, too. I know who I will be living with and I feel like they are my family up here and I need them. It would be hard to come back and not really know anyone.

Dale: Being connected here is such a big deal. For the most part I feel pretty good but I have those down days where I just feel so frustrated because things didn't work out the way I wanted at school. I feel unrecognized and I just get angry and want to be in a place where my work is acknowledged. I know so many staff that feel that way and have kinda' just decided to toe the line and stay out of trouble's way.

Caitlin: Yeah, I know how you feel. The art show was great. The kids loved it and I had a great time with it but no one ever said thanks for doing that. It was almost like it was expected of me. A thanks would have been nice!

Brett: Same thing happened with the iPads in all the classes. I got a grant for us to buy those and did all the set up and training for them and not a single teacher or administration person said anything to me. It would have been nice to be recognized in some way. But I guess I have to remind myself I didn't do it for recognition.

Sue: That was great work, Brett, and Caitlin, your art show was amazing! It can be tough to feel invisible and that's how I feel sometimes. I still, after five years, feel like an outsider. I see the boundaries of what I can and can't be involved in and 
sometimes that makes me feel like all this work goes for nothing. And sometimes I don't know if I have done something wrong, so I worry about stepping on toes.

Brett: Sue! It is not for nothing. At the end of day, we can only focus on the students. Everything else just gets so messy and complicated and can totally mess up my head. I am here to teach and the students are my focus. If I pay attention to being worried about my job all the time, it's just going to eat me up.

Sue: I know. I guess some days I just get down. I also know that as I get closer to retirement, I kind of want to leave on a high note. I don't want to stay and leave angry and bitter and annoyed. I love teaching and I want to finish off still being able to say that.

Dale: OK, guys, this was a good talk but none of us actually answered my original question. Are you coming back next year?

Caitlin: Can we just eat dinner now?!

\section{Discussion}

The complexities of teacher attrition are revealed throughout this dialogue. Factors such as compensation, position instability, contract length, family commitments, school dynamics, administrator roles, geographic location, personal commitments, and financial goals, among others, have been included to reflect the variety of issues that teachers discussed in terms of their own considerations about staying or leaving. Although each of these factors has importance alone, they are often intertwined and individual teachers place different values or weights on those that are more or less meaningful or relevant to them.

\section{Attrition}

One important distinction here is that participants in this case are not discussing their attrition from the profession of teaching; rather, they are discussing their attrition from the teaching force in the community of Grassy Hills. Their decision making is focused on the site of their work as teachers, and is attrition from place, rather than attrition from the profession. Consistent across all participant data is the assumption that it is inevitable that leaving the community will occur. The only question teachers pondered was when.

Single year contracts create a short-term vision of retention, which is problematic for the community in a number of ways. If beginning teachers utilize positions in a First Nation school as a training ground that can be abandoned once teaching skills have been developed, they benefit individually and the next schools they work at also reap benefits. However, schools like Grassy Hills are drained of resources and experience and the First Nation students essentially become subjects and sites where teachers hone their skills and experiment with their practice in ways to refine it and gain the expertise needed to be hired elsewhere, for more permanent positions. When experienced teachers leave, they similarly deprive the community and students of their knowledge and expertise and the school loses mentors for the beginning teachers who are hired. In addition, constant teacher turnover has a negative outcome for students by compromising trust and disrupting school dynamics (York-Barr, Ghere, \& Sommerness, 2007). 
Trust is a foundational component of educational relationships and when teacher turnover is high, establishing those trusting school relationships becomes an ongoing challenge because students become cynical or apathetic and resist relationships as a protective device to avoid feeling betrayed or hurt.

\section{Policy Recommendations}

There are both short- and long-term policy related recommendations that attend to issues teachers in Grassy Hills experience. In the re-storied narrative several issues were raised. Sue's character clearly depicts the role of induction and mentorship support needed and valued by teachers. Brett, Dale, and Caitlyn often refer to the relationships made with community members and emphasize a desire to become connected and involved in community life through coaching and other recreational opportunities, such as hunting, fishing, and skiing. Finally, the re-storied narrative also emphasizes the tensions around decision making with regard to length of tenure. Brett, Sue, Caitlyn, and Dale all discussed their reasons for either staying in the community or leaving. Due to single year contracts in Grassy Hills, this becomes a topic of conversation for all teachers every year. The discussions are about short-term stays rather than settling in for longer term, more secure contracts. How then can the Local Education Authority (LEA) re-envision attrition factors as a plan for retention? In the short-term, induction and orientation programming, community inclusion, and continuous or multi-year contracts are strategies or approaches that could mediate some of the issues raised by the teachers.

Induction and mentoring programs. According to a large body of literature, induction programming, consisting of support, guidance, and orientation, is shown to support retention, particularly in the early stages of a career (Cherubini, 2007; Ingersoll \& Kralik, 2003; Ingersoll \& Smith, 2004). Although many of the teachers in Grassy Hills are not in the early stages of their career, they are in the early stages of their time teaching in a First Nation community and, as such, induction programming would offer support. Given that the teachers are provincially certified and the schools are implementing provincial curriculum, why has the Ontario Ministry of Education's New Teacher Induction Program (NTIP) not been made available to beginning teachers in Grassy Hills? Although Grassy Hills schools are federally funded and the NTIP program is provincial, there have been circumstances in the past where federal-provincial agreements have been negotiated. For example, Grassy Hills schools are inspected by the Ontario Ministry of Education on a regular basis because they implement the Ontario curriculum. Could a similar agreement be established where NTIP is made available to teachers in Grassy Hills? The NTIP is intended to support new teachers through induction, mentorship, and professional development. Built into the NTIP is a process whereby new teachers undergo a formal performance appraisal for the first two years of the program. Supporting performance appraisals of teachers would align with having continuous contracts, ensuring steady progression during the early years of a teacher's practice in Grassy Hills. Where turnover is high and retention is an ongoing struggle, NTIP could be utilized as one foundational component of a retention strategy.

However, the model for induction and mentoring programs would have to be understood differently in a First Nation context. Teaching in Grassy Hills is as much about what happens in the community as what happens in the school and, as such, a mentoring program would require that life in school and beyond the school be supported. Incoming teachers could be partnered with a more experienced teacher and a member of the community The involvement of 
community members, local staff, and Elders would be a necessary component to integrate teaching and learning about Indigenous approaches to child rearing, development, culture, worldview, and community values and dynamics. A model for induction programming that draws on experienced teachers alongside members of the community would also serve to ease disruption during critical transition times. When teacher turnover is high, community members and staff members, such as educational assistants who are primarily from the community, could play an integral role by providing continuity between academic years, which could mediate the negative impact of higher levels of attrition and better support students, new teachers, and the school community.

Implementing an induction or mentoring program that draws on a partnership between teachers and community members would not only orient new teachers to the community and schools but could also potentially better integrate teachers into community activities and community members into school events and programming, promote better relationships and understanding between teachers and community members, and boost retention by decreasing teacher isolation.

Contracts. Continuing, or at least multi-year, contracts could help reduce high teacher turn-over rates and provide a body of more experienced teachers capable of better supporting mentoring and induction programs, alongside members of the community. In Grassy Hills, contract terms are one year and contract offers are re-issued annually based on funding periods and projected student populations. Continuity in the teaching force might assist in stabilizing student populations from year to year and mediate one of the factors that currently dictate single year contracts. However, the LEA would need to maintain authority to end contracts if student populations were low or funding was reduced. In a geographically isolated area, challenges to teachers' work are compounded by a lack of external connection and support from a larger body representing teachers. Creating a stable long-term approach to teacher retention would require that additional support be available for both teachers and the LEA to formally negotiate contracts, resolve grievances, and advocate for improved teaching and learning conditions.

Of course developing community integrated mentoring and induction programs as well as continuous contracts as approaches to boost retention assume involvement and willing participation from the staff, community members, Elders and the LEA. This may or may not be feasible depending on the situation, funding, context, and existing relationships within the community. Although short-term policy recommendations can attend to the immediacy of retention, long-term policy planning also plays a significant role in teacher retention. Teacher education with collaborative stakeholder involvement can play an important role in long-term planning to improve teacher retention in northern and remote First Nation communities.

Teacher Education. In order for short- and long-term policy recommendations to materialize, stakeholders must become engaged and invested in the goal of improving teacher retention in remote First Nation communities. Stakeholders in this systemic long-term approach to improve teacher retention are Faculties of Education across the province, which provide teacher education programs as well as professional development opportunities through additional qualification courses. There are two ways that teacher education can improve teacher retention in First Nation communities. The first recognizes education as a site of reconciliation (Truth and Reconciliation Commission of Canada, 2015). 
One response to the TRC calls to action would be to develop Indigenous teacher education programs and increase teacher education opportunities for members of First Nation communities in the North. Having qualified teachers within the community of Grassy Hills, who are from Grassy Hills, would help to eliminate a number of personal factors which play such a significant role in teacher attrition. However, Faculties of Education will need to meet the needs of First Nation students, recruit more First Nation students, and sustain authentic relationships with First Nation educational stakeholders in remote locations. It must also be noted that teacher education programs directed at supporting the development of Aboriginal teachers to work in their home communities is a high priority for some Faculties of Education that can most adequately attend to the issues of attrition identified here. However, due to the demographics of the participants in this study, the inquiry focused on the experiences of teachers who were not from the community of Grassy Hills. Second, teacher education programs need to better address Aboriginal issues in education and better prepare non-Indigenous teachers for work outside of the southern urban centers of Ontario. Universities can provide undergraduate and teacher education programs that facilitate the integration of Aboriginal perspectives across curriculum.

\section{Conclusion}

Increasing teacher retention in First Nations communities has been identified in the literature, both academic and grey, as requiring attention. When attrition rates are high and teacher efficacy, quality of student experience, and overall academic achievement is compromised, efforts to mobilize plans for stability are needed. The literature has demonstrated various factors contributing to attrition and retention of teachers in First Nations communities, but the remote First Nations educational context in Ontario requires innovative policy and procedural reform to improve teacher retention based on the notion that attrition is inevitable. Through a narrative restorying approach I have introduced a collective dialogue demonstrating the complexity of various attrition factors. In Grassy Hills, the attrition factors were both professional and personal and I have argued that, although teacher attrition is inevitable, particularly because of personal factors, it is necessary to re-envision attrition factors as a plan for retention. Two short-term approaches were outlined to attend to the professional attrition factors with the aim of increasing teacher retention: community integrated induction and mentorship programming, and continuous and multi-year contracts are possible approaches to boost retention. Teacher education is one long-term approach that was outlined to address teacher attrition from a system perspective. In all approaches, collaborative effort, engagement, and funding are needed from the federal government, local education authorities, and Faculties of Education to increase teacher retention in remote First Nation communities. 


\section{References}

Anderson, D., Horton, L., \& Orwick, S. (2004). First Nations teacher education: Issues for First Nations communities. In Chiefs of Ontario (Eds.), The new agenda: A manifesto for First Nations education in Ontario. Toronto, ON: Chiefs of Ontario. Retrieved from http://www.chiefs-of-ontario.org/education/manifesto

Assembly of First Nations. (2012). Soul of sovereignty: The impact of culturally responsive education on the academic achievement of First Nations students. Educational Secretariat of the Assembly of First Nations. Retrieved from http://www.afn.ca/uploads/files/education/soul-of-sovreignty.pdf

Chase, S. E. (2005). Narrative inquiry: Multiple lenses, approaches, voices. In N. K. Denzin \& Y. S. Lincoln (Eds.), The handbook of qualitative research (3rd ed., pp. 651 - 679). Thousand Oaks, CA: Sage

Cherubini, L. (2007). Speaking up and speaking freely: Beginning teachers' critical perceptions of their professional induction. Professional Educator, 29(1), 1 - 12.

Chiefs of Ontario. (2004). Case study of teacher salaries/non-salaries issues. Retrieved from www.chiefs-of-ontario.org

Connelly, F. M., \& Clandinin, D. J. (1990). Stories of experience and narrative inquiry. Educational Researcher, 19(2), 1 - 14.

Creswell, J. W. (2008). Educational research: Planning, conducting, and evaluating quantitative and qualitative research. Upper Saddle River, NJ: Pearson Education.

Drummond, D., \& Rosenbluth, E. K. (2013, December). The debate on First Nations education funding: Minding the gap. Queens University Policy Studies, Working Paper 49. Retrieve from http://www.queensu.ca/sps/working_papers

Ermine, W. (1995). Aboriginal epistemology. In M. Battiste \& J. Barman (Eds.), First Nations education in Canada (pp. 101 - 112). Vancouver, BC: UBC Press.

Ingersoll, R., \& Kralik, J. (2003). A review of empirical research in the effects of teacher mentoring programs in elementary and secondary schools. Denver, CO: The Education Commission of the States.

Ingersoll, R., \& Smith, T. (2004). Do teacher induction and mentoring matter? National Association of Secondary School Principles Bulletin, 88(638), 28 - 40.

Kitchenham, A., \& Chasteauneuf, C. (2010). Teacher supply and demand: Issues in northern Canada. Canadian Journal of Education, 33(4), 869 - 896.

Mueller, R., Carr-Stewart, S., Steeves, L., \& Marshall, J. (2012). Teacher recruitment and retention in select First Nations schools. in education, 17(3), 56 - 71.

Oshkineegish, M., \& Berger, P. (2013). The role of the non-Native teacher in remote First Nations communities. Canadian Journal of Native Studies, 36(1), 113 - 125 
Paquette, J., \& Fallon, G. (2010). First Nations education policy in Canada: Progress or gridlock? Toronto, ON: University of Toronto Press.

Pinnegar, S., \& Daynes, G. D. (2007). Locating narrative inquiry historically. In D. J. Clandinin (Ed.), Handbook of narrative inquiry: Mapping a methodology (pp. 3 - 34). Thousand Oaks, CA: Sage.

Simpson, L. (2000). Anishinaabe ways of knowing. In J. Oakes, R. Riew, S. Koolage, L. Simpson, \& N. Schuster (Eds.), Aboriginal health, identity and resources (pp. 165 - 185). Winnipeg, MB: Native Studies Press.

Statistics Canada. (2008). Aboriginal identity population by age groups, median age and sex, 2006 counts, for Canada and census metropolitan areas and census agglomerations20\% sample data (table). Aboriginal Peoples Highlight Tables. 2006b Census. Statistics Canada Catalogue no. 97-558-XWE2006002. Ottawa. Released January 15, 2008. http://www12.statcan.ca/english/census06/data/highlights/aboriginal/index.cfm?Lang=E

Truth and Reconciliation Commission of Canada. (2015). Calls to Action. Retrieved from http://www.trc.ca/websites/trcinstitution/index.php?p=3

Wilson, S. (2007). Guest editorial: What is an Indigenist research paradigm? Canadian Journal of Native Education, 30(2), 193 - 195.

Wotherspoon, T. (2006). Teachers' work in Canadian Aboriginal communities. Comparative Education Review, 50(4), 672 - 693.

Wotherspoon, T. (2008). Teachers' work intensification and educational contradictions in Aboriginal communities. Canadian Review of Sociology, 45(4), 389 - 419.

York-Barr, J., Ghere, G. S., \& Sommerness, J. (2007). Collaborative teaching to increase ELL student learning. Journal of Education for Students Placed at Risk, 12(3), 1 - 34. 